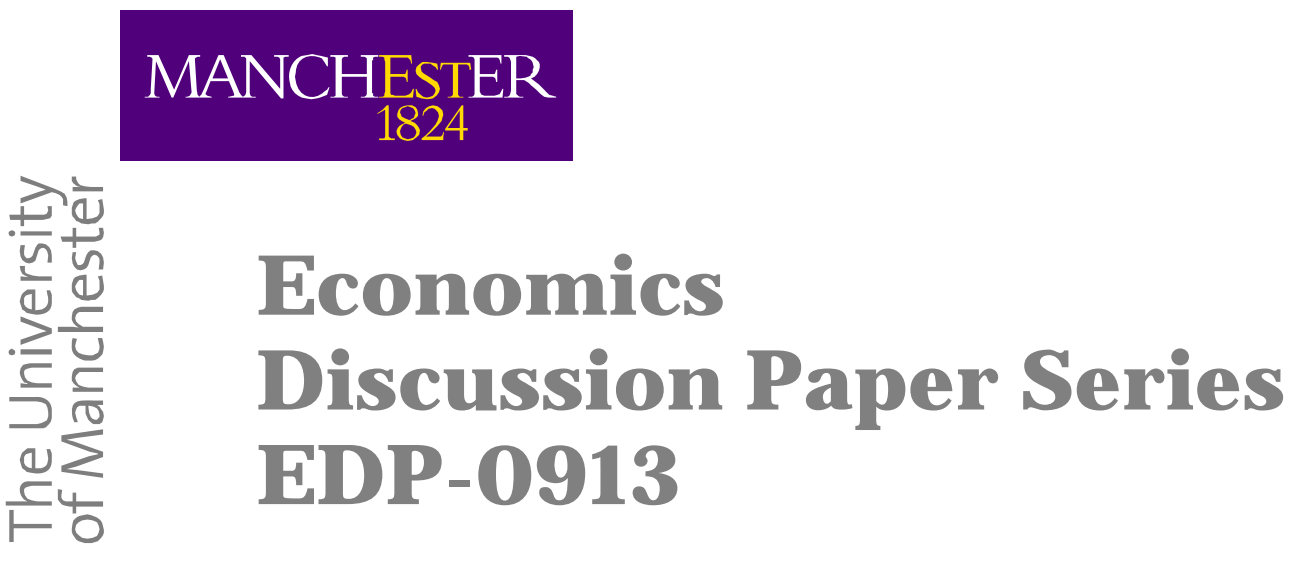

\title{
Poverty and Vulnerability in Rural China: Effects of Taxation
}

\author{
Katsushi Imai \\ Xiaobing Wang \\ Woojin Kang
}

August 2009

Economics

School of Social Sciences

The University of Manchester

Manchester M13 9PL 


\title{
Poverty and Vulnerability in Rural China: Effects of Taxation ${ }^{1}$
}

\author{
Katsushi S. Imai* \\ Economics, School of Social Sciences, University of Manchester, the UK \\ Xiaobing Wang \\ Economics, School of Social Sciences, University of Manchester, the UK \\ Woojin Kang \\ Economics, School of Social Sciences, University of Manchester, the UK \\ $6^{\text {th }}$ August 2009
}

\begin{abstract}
This paper studies the impact of taxation on poverty and ex ante vulnerability of households in rural China based on national household survey data in 1988, 1995 and 2002. It has been confirmed that i) poverty and vulnerability have reduced significantly with a great deal of geographical disparity, ii) education, land, and access to infrastructure and irrigation facilities are among the key factors to reduce vulnerability, and iii) the highly regressive tax system increased farmer's poverty and vulnerability. The abolishment of rural tax since 2006 would thus have a significant negative impact on both poverty and vulnerability of rural households.
\end{abstract}

\section{JEL Classification: C23 C61 I31 I32}

Keywords: Poverty, Vulnerability, Taxation, Rural China

*Corresponding Author; Katsushi S. Imai (Dr.) Economics, School of Social Sciences, University of Manchester, Arthur Lewis Building, Oxford Road, Manchester M13 9PL, UK; Telephone: +44-(0)161-275-4827, Fax: +44-(0)161-275-4812 Email: Katsushi.Imai@ manchester.ac.uk

\footnotetext{
${ }^{1}$ This paper was presented at the First International Symposium of Comparative Research on Major Regional Powers in Eurasia in Japanese: the Elusive Balance: Regional Powers and the Search for Sustainable Development, at Hokkaido University and at Kobe University in July 2009. The authors thank Akira Uegaki, Shinichiro Tabata, Go Koshino, and Takahiro Sato who organise the symposium and the participants for their useful comments. They have benefited from advice from Raghav Gaiha, Raghbendra Jha and Armando Barrientos. The study is funded by the small fund from DFID and Chronic Poverty Research Centre in the UK under the DFID project on social protection and poverty led by Armando Barrientos, at Brooks World Poverty Institute (BWPI) of University of Manchester. The views expressed are, however, those of the authors' and do not represent the organisation to which they are affiliated.
} 


\section{Poverty and Vulnerability in Rural China: Effects of Taxation}

\section{Introduction}

The Chinese economy has been growing at around $10 \%$ per annum since the reforms began in 1978. However, inequality has risen across the region and during most of the period, for example, the urban-rural income gap in China is now amongst the biggest in the world and this would be even bigger once the differences in the standard of living (e.g. in terms of health or education), welfare benefits and infrastructure between the two groups were taken into account (e.g. Sicular et al., 2007, Ravallion and Chen, 2007, Wan and Zhang, 2006).

The increasing inequality in China implies that not everyone had enjoyed the fruits of the reform and growth evenly. This is closely associated with the persistence of poverty for a certain proportion of the population. According to the official poverty line set by the government, poverty has dramatically reduced from around 20 percent in 1979 to 3 percent in 2006. However, Ravallion and Chen (2008) showed that based on the new international $\$ 1.25$ a day poverty line a substantially higher poverty rate for China than past estimates, with about 15 percent of the population living in consumption poverty in 2005.

Much has been done on poverty and inequality of China, but there are only a handful of works on vulnerability. However, the measure of vulnerability is an very important indicator of development as the welfare of a household depends not only on its present income or consumption, but also on the risks it faces. Among them, Zhang and Wan (2006) explored whether diversification and education affect vulnerability in rural China, and found that diversification into non-agriculture activities is found to exert little effects 
on vulnerability, and that education is an important determinant of vulnerability in rural China. In a more recent study, You, Walters, and Wang (2009) have found that vulnerability consistently increases during the period 1989-2006 and that in rural China the households' well-being has been deteriorated in terms of both 'vulnerability as expected low utility' based on Ligon and Schechter (2003) and 'per capita consumption level of those who lie at the bottom of distribution of consumption'. Until recently, China had long taken "growth" oriented anti-poverty policy, that is, the policy which prioritises growth promotion over redistribution, but this does not appear to have been entirely successful in achieving its goal. On the other hand, using the China Health and Nutrition Survey (CHNS) in the period 1989-2004, Zhang and Wan (2008) compare the vulnerability as the probability of the household falling into poverty and actually observed poverty and find that setting the line at 50 per cent in order to improve predictive power, which generally supports Chaudhuri's ex ante measure of vulnerability as predicted poverty (Chaudhuri, Jalan, and Suryahadi, 2002; Chaudhuri, 2003).

One of the main reasons for the rural-urban disparity as well as the overall inequality is the highly regressive Chinese tax system where the rural poor had to pay disproportionally high share of income tax in the form of agricultural tax (Wang and Piesse, 2009). Although the incomes of rural households were much lower than those of their urban counterparts, rural households were taxed much more heavily than their urban counterparts (Tao and Liu 2005). This highly regressive tax system put those at the bottom of the income distribution and made them extremely vulnerable, which would justify our study of the impact of this tax system on vulnerability. Building upon Wang and Piesse (2009), the present study examines the regional pattern of vulnerability, the 
evolution of vulnerability and the impacts of taxation on poverty and vulnerability in rural China. With regard to the methodology, the present study applies Chaudhuri' ex ante measure of vulnerability to the nationally representative household survey data in 1988, 1995 and 2002 in order to identify household incomes, the burden of taxation and their impacts on rural residents' welfare status in terms of vulnerability and expected poverty in rural China.

The contribution of this paper to the literature of poverty in China is threefold. First, this is the first study to analyse the impact of rural taxation on people' welfare in term of vulnerability. Second, we show that a small tax burden can be "the last straw on the camel's back", which can make people in the lower income end extremely vulnerable, although it may have relative small impact on poverty. Thirdly, it provides rationales for the abolishment of the agriculture tax as well as the associated fees and charges in 2006 as it shows the significant negative impact of these taxes on rural people's welfare.

The rest of the paper is organized as follows. The next section briefly reviews the literature on taxation in China. Section 3 summarises the data to be followed by the discussion of econometric models and specifications in Section 4. The empirical results are presented in Section 5. Section 6 concludes with a discussion of the implications of the policy on taxes where the importance of tax reform is emphasised as a policy to encourage a more equitable distribution of income and greatly reduce poverty and vulnerability of rural households. 


\section{China's Rural Tax System and Tax Reform}

There were two types of taxes related to urban and rural households in China: income tax and agricultural tax. There is a universal requirement to pay income tax when incomes are above a certain benchmark, which is a progressive regime by law. Rural residents have to pay agriculture tax because they live in a rural area and have rural Hukou, the system of residency permits which dates back to ancient China where household registration is required by law.

The income tax legislation in China was passed in 1980, with the tax threshold set at 800 yuan a month, 20 times higher than the average monthly wage at that time of 40 yuan. This rate did not change until 2006, when the benchmark income for taxation was increased to 1600 Yuan. Because of the high tax threshold, the vast majority of rural residents would not be liable for tax. However, in reality the tax system was highly inconsistent: the actual tax liability for the rural population was determined by the number of family members and the cropland acreage under their management, not the income of the household.

The agriculture tax is a liability on all companies and individuals that produce farm output or have income from agriculture. It is assumed that rural households are involved in agricultural production although in some cases that is not true. This tax adopts the flat rates which are differentiated at regional level and constant irrespective of income levels for all households in each region. According to the Agriculture Tax Regulations, the national average rate is $15.5 \%$ of the value of the yield in a normal year. In most cases, the Agriculture Tax is paid in kind, supplemented by currency. The tax on agricultural specialties is computed on an ad valorem basis, with a rate between $5 \%$ and $25 \%$. There 
is another main item levied on the rural population: fees and administrative charges. These charges have to be paid to the village for social welfare, infrastructure and management and to the township for education, family planning, paramilitary support, infrastructure and irrigation. However, most of those services never received or the work not done, despite payment that are made (Knight and Song, 1999).

Since the mid-1990s until 2004 when the recent tax reform was implemented, the rural tax burden remained heavy simply due to the need to support the functions of local government ( $\mathrm{Lu}$ and Wiemer, 2005). Overall, there have been hundreds of different kinds of taxes and fees imposed on farmers by various levels of government and organisations. In order to relieve farmers' financial burdens, central government introduced the fees-fortax plan in early 2000, which required farmers to pay only the agricultural tax, the special agricultural product tax and few additional taxes. The Tax of Special Agricultural Products is a major item in rural areas and is levied on rural people who produce almost all special local products, including fruits, flowers and mushrooms as well as aquatic products. This was imposed at an average tax rate of $8 \%$. According to the China Statistic Yearbook, the income from agricultural taxes made up 39\% of the total national financial revenue in 1950 . This proportion declined to $4.6 \%$ in 1995 and to $3.7 \%$ in 2000 . At the national level, the share of agricultural taxes to total tax is decreasing. However, the share of agriculture tax to value added in agriculture is increasing, which means that the tax burden in rural areas is heavier than before. This tax, which accounts for a small part of government revenue, means large financial burdens for farmers who have suffered consecutive falls in their income growth. Official figures (China Statistic Yearbook) 
suggest that farmers' per capita income grew around 4\% after 1996, far below the income growth of urban residents or of GDP growth.

Wang and Piesse's study (2009) shows that the system of taxation has significantly contributed to inequality between the urban and rural over the past two decades. Some

reform has now been implemented and since 2004 the Tax of Special Agricultural Products has been cancelled except that on tobacco. The agricultural tax was exempted in most provinces in 2005 and waived across the country in 2006. Because of this reform, fees and administrative charges that levied with this tax lost its legitimacy and became forbidden. Although there are still some small fees introduced by some local government, rural residents' burden has been greatly reduced.

\section{Data}

The data used in this study are three cross sectional national household surveys, the Chinese Household Income Project (CHIP) for 1988, 1995 and 2002. The data in all three surveys were drawn from a large-scale sample selected by the National Bureau of Statistics (NBS) from the annual household survey (approximately 65,000 rural households and 35,000 urban households) using a multistage, stratified probability sampling method, which is designed in such a way that households are randomly sampled in each province. The large sample size would make our study of vulnerability unique in the literature. The original CHIP 1988 dataset has 51,352 rural residents. The original CHIP 1995 dataset has 34,739 rural residents. The CHIP 2002 dataset has 37,968 rural residents. 
All three rounds of the survey cover more than half of the Chinese provinces, with representative province from different regions, although the distribution is not absolutely even. This allows us to study regional disparity in China. The dynamic change of poverty and vulnerability can be assessed by the use of repeated cross-sectional data sets in three years, 1988, 1995 and 2002 spread over this fourteen-year period. The construction of household panel data is not feasible.

The CHIP data sets are considered the best publicly available data source on household income and expenditures and its geographical coverage is unique as it covers provinces in the eastern, central, and western regions of China (Riskin, Zhao and Li 2001). They still remain the only source of household-level data on income and other individual and household characteristics in China. They also provide the only comprehensive database of household income which would overcome the limitations of the published income data in China based on official definitions and census data. Detailed analyses of the CHIP surveys are published in Griffin and Zhao (1993) and Riskin, Zhao, and Li (2001), and Gustafsson, Li and Sicular (2008).

In this paper, a rural household refers to a group of members of the household that have rural Hukou, that is, have registered with the police as rural residents and are living and sharing economic resources as a unit. Household income is based on cash payments and a broad range of additional components, such as, payments in kind valued at market prices, agricultural output produced for self-consumption valued also at market prices, the value of food and other direct subsidies, and the imputed value of housing services. Total disposable household income refers to the sum of income from various activities by members of rural households, includes wages and salaries, net business income, income 
from property and income from transfers provided by members of the household, but excludes income from selling properties and funds that are borrowed. Income per person is calculated by the total household income per year divided by the number of household members.

We define tax into two parts: the agricultural tax by the state and the fees and charges by the local governments. The latter is more difficult to predict, which introduces uncertainty to the estimate of household poverty or vulnerability. The agricultural taxes cover taxes on primary, secondary and tertiary sector activities paid to state and local government, and miscellaneous fees paid to the state and collectives. Fees include various items, including surcharges, fees retained by villages and townships, ad hoc fees, and various apportions and contributions to fund-raising, which are paid by households, in cash and in kind, with respect to their production and operations. The present study analyses the effects of taxes and fees on household poverty and vulnerability in rural areas.

\section{Methodology}

It is not straightforward to analyse the effects of tax and fees on household poverty or vulnerability as they are either direct or indirect. While direct effects are the decrease of poverty or vulnerability due to the increase in disposal income after tax, indirect effects are associated with (i) the reduction of market distortion or any disincentive effects in the flat tax system where a household has to pay the more or less same amount of agricultural tax or fees regardless of the income levels, (ii) the change in central or local government fiscal system which would affect the public expenditure in infrastructure or other health 
or education and the resulting changes in multiplier or second round effects, (iii) the political economy effect which could be influenced by the share of tax in various sectors in the economy (e.g. the share of government's tax income from either urban or rural areas; from either agricultural, manufacturing, or service sectors), and (iv) the reduction of vulnerability as a result of the change in the expectation of future disposal income (e.g. due to the abolition, or reduction of agricultural taxes and fees). Capturing a part of these indirect effects would necessitate the comparison of actual poverty or vulnerability with its counterfactuals, but it is not easy to estimate the latter as the relevant data are not easily available. ${ }^{2}$ The present study thus focuses only on the direct effects as well as the last component of the indirect effects (or (iv)) by simply comparing the impact of tax on the welfare of rural household on poverty incidence and vulnerability through the change of household disposal income before and after tax. If the tax is progressive, we would expect a drop in poverty and vulnerability after tax. On the contrary, if the tax is regressive, poverty and vulnerability are likely to increase. However, the effects of tax on poverty and on vulnerability are not necessarily same because the latter is associated with the household members' perception of future welfare. If the abolition of tax reduces to some extent the future uncertainty of household income, the reduction of vulnerability after tax may be larger than that of poverty. For poverty, we report the impact of tax on rural poverty in terms of the change in the head count ratio. For vulnerability, ex ante measure of vulnerability, or Vulnerability as "Expected Poverty" (VEP) is used (Chaudhuri, Jalan, and Suryahadi, 2002; Chaudhuri, 2003, Suryahadi and Sumarto,

\footnotetext{
${ }^{2}$ See Imai (2007) for the example of analysing the effects of government policy on poverty in India using the counter-factual approach based on village-level social accounting matrices.
} 
2003). We derive VEP measures for poverty based on household income before and after $\operatorname{tax}$.

\section{Vulnerability as expected poverty $(\mathrm{VEP})^{3}$}

In this subsection we provide a brief summary of the estimation procedure of estimating vulnerability to poverty. First, using record level household data, the FGT measure of head-count poverty (Foster, Greer, and Thorbecke, 1984) is calculated. Second, household's expected consumption and its variance of the error term are estimated using Feasible Generalized Least Square (FGLS) estimation procedure. Household's vulnerability to poverty is then derived as the conditional probability of the household falling into poverty in the next period.

The main aim of a forward looking vulnerability to poverty estimation is to have an estimate of household's over time mean and variance of consumption expenditures. Ideally, this requires panel data collected over a sufficiently long period. However, as noted by Jalan and Ravallion (2001), most of the available standard data sources are based on a cross section household survey and cannot be used for this purpose. In this study, we use the VEP measure developed for large cross-section data. Vulnerability is defined as expected poverty, or the probability that a household's consumption will lie below the predetermined poverty line in the near future.

For a given household $h$, the vulnerability is defined as the probability of its consumption being below poverty line at time $t+1$ :

\footnotetext{
${ }^{3}$ This sub-section is based on Azam and Imai (2009) and Gaiha and Imai (2009). See also Hoddinott and Quisumbing (2003a, b) who provide a comprehensive review of recent approaches and a 'toolkit' to quantify vulnerability of households and data requirements.
} 
$V_{h t}=\operatorname{Pr}\left(\ln c_{h, t+1}<\ln \underline{c}\right)$

where $V_{h t}$ is vulnerability of household $h$ at time $t, c_{h, t+1}$ denote the consumption of household $h$ at time $t+1$ and $\underline{c}$ stands for the poverty line of household consumption.

Assuming that for household $h$ the consumption function is specified as

$\ln c_{h}=X_{h} \beta+\varepsilon_{h}$

where $c_{h}$ stands for per capita consumption expenditure for household $h, X_{h}$ represents a vector of observable household and other determinants, $\beta$ is a vector of parameters, and $\varepsilon_{h}$ is a mean-zero disturbance term that captures household's idiosyncratic shocks. Consumption expenditures, $c_{h}$ is assumed to be log-normally distributed and as such the disturbance term, $\varepsilon_{h}$ will be distributed normally.

The vulnerability of household, $h$ with characteristics $X_{h}$ can now be calculated using the coefficient estimates of the equation (1) in the following manner:

$$
\hat{V}_{h}=\hat{\operatorname{Pr}}\left(\ln c_{h}<\ln \underset{-}{c} \mid X_{h}\right)=\Phi\left(\frac{\ln \underline{-}_{-} X_{h} \hat{\beta}}{\hat{\sigma}}\right)
$$

where $\hat{V}_{h}$ denotes vulnerability to poverty, that is the probability that the per capita consumption level $\left(c_{h}\right)$ will be lower than the poverty line $(\underline{c})$ conditional on household characteristics $X_{h}$. Meanwhile, $\Phi($.$) denotes the cumulative density of the standard$ normal distribution and $\hat{\sigma}$ is the standard error of the equation (1).

Households future consumption is further assumed to depend upon uncertainty about some idiosyncratic and community characteristics. To have consistent estimate of 
parameters, it is necessary to allow heteroscedasticity, that is, variances of the disturbance term to vary. This can take the following functional form:

$$
\sigma_{e, h}^{2}=Z_{h} \theta=\sum_{i} \sum_{j \geq i} X_{h}^{i} X_{h}^{j} \theta_{i j}+\eta_{h}
$$

A three-step Feasible Generalised Least Squares (FGLS) procedure can be used to estimate the parameter, $\theta$. Equation (1) is first estimated using an ordinary least squares (OLS) procedure. Then, the estimated residuals from the equation (1) are used to estimate the following equation, again by OLS:

$$
\hat{e}^{2}{ }_{O L S, h}=Z_{h} \theta+\eta_{h}=\sum_{i} \sum_{j \geq i} X_{h}^{i} X_{h}^{j} \theta_{i j}+\eta_{h}
$$

The estimate from above is then used to transform the equation (4) into the following:

$$
\frac{\hat{\boldsymbol{e}}^{2}}{Z_{h} \hat{\boldsymbol{\theta}}_{\text {OLS }}}=\left(\frac{Z_{h}}{Z_{h} \hat{\boldsymbol{\theta}}_{O L S}}\right) \theta+\frac{\eta_{h}}{Z_{h} \hat{\boldsymbol{\theta}}_{O L S}}
$$

This transformed equation is estimated using OLS to obtain an asymptotically efficient FGLS estimate, $\hat{\theta}_{F G L S} . Z_{h} \hat{\theta}_{F G L S}$ is a consistent estimate of $\sigma_{e, h}^{2}$, which is the variance of the idiosyncratic component of household consumption.

This is then used to transform the equation (1) into:

$$
\frac{\ln c_{h}}{\sqrt{Z_{h} \hat{\theta}_{F G L S}}}=\left(\frac{X_{h}}{\sqrt{Z_{h} \hat{\theta}_{F G L S}}}\right) \beta+\frac{e_{h}}{\sqrt{Z_{h} \hat{\theta}_{F G L S}}}
$$

OLS estimation of the equation (6) yields a consistent and asymptotically efficient estimate of $\beta$. The standard error of the estimated coefficient, $\hat{\beta}_{F G L S}$, can be obtained by dividing the reported standard error by the standard error of the regression. Finally, the estimates of $\beta$ and $\theta$ obtained through this FGLS method can be used to estimate the 
vulnerability to poverty of household $h$ through the following generalisation of the equation (2):

$$
\hat{V}_{h}=\Phi\left(\frac{\ln c-X_{h} \hat{\beta}}{\sqrt{\sum_{i} \sum_{j \geq i} X_{h}^{i} X_{h}^{j} \hat{\theta}_{i j}}}\right)
$$

Clearly, estimation of vulnerability to poverty depends on the following elements: the distributional assumption of normality of $\log$ consumption, the choice of poverty line $\underline{c}$, the expected level of log consumption and the expected variability of log consumption. The higher the level of expected consumption and expected consumption variability the lower the vulnerability is.

As noted earlier, a merit of this vulnerability measure is that it can be estimated with cross section data. However, the measure correctly reflects a households' vulnerability only if the distribution of consumption across households, given the household characteristics at time $t$ represents time-series variation of household consumption. Hence this measure requires a large sample in which some households experience good times and others suffer from some kind of negative shocks. Also the measure is unlikely to reflect large unexpected shocks, if we use the cross-section data for a normal year.

It is evident from the literature and the empirical studies that vulnerability is a closely related but distinct concept from poverty on a number of counts. Vulnerability is a dynamic concept from poverty which is essentially a static concept. The model below is used to examine the determinants of vulnerability to poverty in China. This is implemented using the following regression model:

$$
\hat{V}_{h t}=X_{h} \psi+\mu
$$


Where $\hat{V}_{h t}$ is the estimated vulnerability by (7), $X_{h}$ is the vector of household idiosyncratic characteristics, $\psi$ is a vector of coefficients and $\mu$ the error term.

Any operationally useful assessment of households' vulnerability status depends essentially on two important factors: first, the choice of a vulnerability threshold, that is, a minimum level of vulnerability above which all households are defined to be vulnerable and second, specifying the time horizon over which households' vulnerability is to be assessed. There is, however, a certain degree of arbitrariness involved in making such decisions.

The most preferred and natural candidate for the vulnerability threshold is 0.5 . This midway dividing point has three attractive features (Suryahadi and Sumarto, 2003). Firstly, this is the point in the equation (7) where the expected log consumption coincides with the log of the poverty line. Secondly, it makes intuitive sense to say a household is 'vulnerable' if it faces a 50 percent or higher probability of falling into poverty in the near future. Thirdly, if a household is just at the poverty line and faces a mean zero shock, then this household has a one period ahead vulnerability of 0.5 . This implies that, in the limit, as the time horizon goes to zero, then being 'currently in poverty' and being 'currently vulnerable to poverty' coincide (Pritchett, Suryahadi, and Sumarto, 2000). Another threshold that makes sense is the observed headcount ratio. The underlying logic is that 'because the observed poverty rate represents the mean vulnerability level in the population, anyone whose vulnerability level lies above this threshold faces a risk of poverty that is greater than the average risk in the population and hence can be legitimately included among the vulnerable' Chaudhuri (2003, p.11). In practice, however, most of the empirical studies adopted the vulnerability threshold of 0.5. This is 
empirically supported by Wan and Zhang (2006) and we adopt the same threshold in our study.

The other but not less important aspect of an operationally useful vulnerability index is to decide on a time horizon over which households' vulnerability is to be assessed. The existing literature again is of little help in this regard. In most of the cases, time horizon is defined through some arbitrary expression like 'probability of falling into poverty in the near future' providing indication that there is no obvious choice. Recognising that a certain degree of arbitrariness is needed, Chaudhuri (2003) proposed two possible cases a time horizon of one year, which can be thought of in terms of the likelihood of poverty in the short run, and a time horizon of three years which roughly corresponds to the likelihood of poverty in the medium-term. In the later case all households experience poverty spell at least once in the next three years are categorised as vulnerable. The present study adopts the former definition, but the pattern of the results will not be affected if we take other definitions.

In the actual estimation of vulnerability, however, we will use log per capita household income instead of $\log$ per capita consumption, $\ln c_{h}$ because (i) we are interested in the effects of tax on income, (ii) CHIP data are more suitable for analysing income poverty than consumption poverty as they provide much more detailed and reliable data of household income and (iii) the literature of poverty studies on China has mainly focused on income poverty, not consumption poverty. $X_{h}$, the determinants of log per capita household income used in our study includes (i) the characteristics of household head, such as, the age of household head and its square, whether the head is married, the educational attainment of household head, (ii) household composition, such 
as the share of female members in the total household members and dependency burden, (iii) whether the household belongs to the ethnic majority or minority, (iv) the size of the household's farm land and the share of the farm land irrigated and its squares, (v) a vector of regional dummy variables, and (vi) infrastructure (whether the household belongs to the village with power supply or not).

\section{Results}

This section discusses the results based on three rounds of CHIP data sets in 1988, 1995, and 2002. While rural poverty declined in the period 1988-2002, it should be noted that poverty rates calculated based on income 'after tax' is much higher than 'before tax'.

Table 1 indicates that tax system in China has been regressive over the years, though it is getting less regressive in 2002 . The average tax rate of the bottom 10 per cent decile was 7.61 larger than the top 10 per cent decile in $1988,10.53$ in 1995 and 6.36 in 2002 . It should be noted that since 2004 the tax of special agricultural products has been cancelled except that on tobacco and that the agricultural tax was exempted in most provinces in 2005 and waived across the country in 2006.

\section{(Table 1 to be inserted around here)}

Table 2 compares the poverty headcount ratios before and after tax in 1988, 1995, and 2002. Two cases are considered. The first case or Case (A) is the case 'After tax' where we use the disposal income after subtracting all the agricultural taxes, fees and administrative charges, including land contract fees. It is noted that in rural China land 
contract fees are often charged even if households do not own any land. The second case, or Case (B) is 'Before tax' where we use the income before subtracting the agricultural taxes, fees and administrative charges. We apply two different poverty lines following Khan (2008). The lower poverty line is changed from 367 yuan in 1988, to 810 yuan in 1995 and 876 yuan in 2002. The upper poverty lines are 525 in 1988, 1157 in 1995 and 1252 in 2002.

For both cases before and after tax, poverty declined dramatically from 1988 to 2002 . In the first case of 'After tax' (Case (A)), poverty based on the lower poverty line declined moderately from $12.7 \%$ in 1988 to $12.3 \%$ in 1995 and then was further reduced to $7.0 \%$ in 2002 . Poverty based on the higher poverty line shows the similar trend from $32.2 \%$ in $1988,28.1 \%$ in 1995 and to $16.9 \%$ in 2002. The second case of 'Before tax' (Case (B)) showed the similar trends. Poverty based on the lower poverty line declined from $12.7 \%$ in 1988 to $10.2 \%$ in 1995 and to $5.9 \%$ in 2002 . Poverty based on the higher poverty line changed from $29.1 \%$ in $1988,24.1 \%$ in 1995 , and to $15.1 \%$ in 2002 . The difference of Case (A) and Case (B) shows the direct effect of tax on poverty. It is noted that the tax effect on poverty reduced over time. For example, for the lower poverty line, the difference of the two cases reduced from $2.4 \%$ in $1988,2.1 \%$ in 1995 , to $1.1 \%$ in 2002. This was due to the agricultural tax reform being partially implemented in 2002 .

\section{(Table 2 to be inserted around here)}

Table 3 provides the results of VEP, Vulnerability as Expected Poverty. We estimate the equation (1) and the equation (3) for the variance of the error term based on log per capita household income. The definitions of explanatory variables are listed in the 
Appendix. A brief summary of the results is given below. It is noted that regression results are based on the cases where a dependent variable is 'per capita income after tax', but the similar results are obtained if 'per capita income before tax' is regressed.

\section{(Table 3 to be inserted around here)}

Most of the econometric results in Table 3 are intuitive- showing more or less the same coefficient estimates for 1988, 1995 and 2002 with a few exceptions. Below, we mainly focus on the results for the log per capita income function. Household head's age is negative and significant (and its square is positive and not significant) only in 2002, which implies that the household with an older household head tends to have a lower income with a nonlinear effect. A dummy variable on whether the household head is married is negative and significant at $10 \%$ level only in 1988 and not significant in 1995 or 2002. This implies that the marital status of the head is not much related to per capita household income. The share of female member in the household members as well as the dependency burden (or the share of household members under 15 years old or above 65 years old in household members) is negative and significant for all the three years. The share of numbers of members of the communist party is positive and significant for three rounds. This does not necessarily mean that members of the communist party get special treatment but could be as a result of ex ante superior personal abilities that are not controlled in our estimation. A dummy variable on whether the household belongs to ethnic majority is positive and significant, which implies that the ethnic minority group on average enjoys much less per capita household income. Also significant are a set of dummy variables on whether the household head completes various levels of education, 
namely, elementary school, lower middle school, upper middle school, technical school and college or education. The results suggest that education is generally an important determinant of log income. However, the higher level of education becomes more important as a determinant of log per capita income in later years. For example, 'elementary school dummy' is positive and significant only in 1988, 'lower middle school dummy' is positive and significant only in 1988 and 1995, and 'higher education dummy' is positive and significant only in 1995 and 2002.

While the size of the household's farm land is not significant, the share of irrigated land in the total farm land and its square are positive and significant in 1988. A set of regional dummies are highly significant to reflect the regional disparity of per capita log household income. For example, a dummy variable for East Coast or South Coast is positive and significant. That is, those living in rural areas in coastal regions tend to have higher income than those in the rest. Negative and significant coefficient estimates are found for the dummy variables on 'Middle Yellow River Region', 'South West', 'North West', 'Hilly Area' and 'Mountain Area'. A dummy variable to capture the infrastructure, whether the household belongs to the village with power supply, is positive and significant for all the three years.

Table 4 shows that the share of the households with high degree of vulnerability declined dramatically over the years for both cases, Case (A) after tax and Case (B) before tax. Here households are classified into three groups according to the vulnerability estimate. The first group of the households is 'the high vulnerable' with $\hat{V}_{h t} \leq 0.5$, the second is 'the low vulnerable' $0.25 \leq \hat{V}_{h t}<0.5$, and 'the non vulnerable' with 
$\hat{V}_{h t} \leq 0.25$. While the share of the first and the second groups declined over the years, that of the third group increased. That is, as poverty reduced over the years, so did vulnerability. Table 4 also suggests that the agricultural tax and fees increased vulnerability. Together with Table 1, Table 4 implies that the current policy to abolish agricultural tax and fees would reduce both poverty and vulnerability.

(Table 4 to be inserted around here)

The first three columns of Table 5 show the results of probit model for static poverty based on the upper poverty line (where the dependent variable is whether the household is poor or not), whilst the last three columns of Table 5 report the results of OLS for the (estimated) vulnerability or VEP measure based on Case (A), 'Income after tax'. With a few exceptions, the signs of coefficient estimates in Table 5 are opposite to those in Table 3 where $\log$ per capita household income is estimated. The results of probit model for static poverty in the first three columns of Table 5 are similar to those of OLS for vulnerability estimates in the last three columns of Table 5. To save the space, we focus only on the differences of the results for static poverty and vulnerability.

\section{(Table 5 to be inserted around here)}

First, in 1995 the characteristics of the household head (that is, age and its square and his or her marital status) are significant for the vulnerability, not for poverty. Second, the farm land size is positive and significant for vulnerability in 1988, 1995, and 2002, but not for poverty. This suggests that after controlling for household characteristics, smaller farmers or the landless may not necessarily be poorer, bur more vulnerable than larger 
farmers. The share of the farm land irrigated is negative and significant for poverty only in 1988, but negative and significant for vulnerability in all the three years. This implies the more pronounced role of irrigation to reduce vulnerability of farming households. Third, the results of regional dummies show the generally similar pattern for poverty and vulnerability. That is, households in East and South Coast regions are less poor as well as less vulnerable, while those living in 'Middle Yellow River Region' or 'Mountain Areas' are poorer and more vulnerable. In 2002, however, there are a few variables to show the different coefficient estimates from those in previous years, particularly for vulnerability. For example, it is noted with regard to the vulnerability estimate in 2002 that 'North Coast' is positive and significant (while it is positive and non-significant in the same year), 'North West' is negative and significant (while it is positive and significant for poverty), and 'Hilly Area' is negative and significant (while it is positive and nonsignificant). The better infrastructure (in terms of electricity supply) tends to reduce both poverty and vulnerability. The results in Table 5 suggest that while poverty is closely associated with vulnerability, the latter is a distinct concept from the former because there are factors only associated with vulnerability, not poverty and vice versa.

Table 6 summarises the regional distribution of poverty and vulnerability based on the upper poverty line in China. Three conclusions can be drawn here. First, there is a considerable regional disparity in both poverty and vulnerability in China. While both poverty and vulnerability are close to zero in some regions or provinces (e.g. Beijing, Jiangsu, Guangdong), they are high, e.g., in Guizhou, Yunnan, Shaanxi or Gansu. Second, in most of the regions, both poverty and vulnerability declined over the years. In general vulnerability declined in a faster pace from 1995 to 2002. Third, while poverty and 
vulnerability move in the same direction in most cases, there is no one to one

correspondence. For example, in 2002, poverty head count ratio in Yunnan, Shaanxi and Gansu are ranged around 40\% (38.8\%- 40.4\%), VEP is 17.1 in Yunnan, 7.01 in Shaanxi and 11.09 in Gansu. A further investigation is necessary to explain why VEP is high or low in the province with the similar level of poverty.

(Table 6 to be inserted around here) 


\section{Conclusion}

Drawing upon three comparable national representative household surveys for China in 1988, 1995 and 2002, this paper studies the impact of taxation on poverty and vulnerability of households in rural China. We have found the following: 1) poverty and vulnerability have reduced significantly in China during the reform period from 1988 to 2002 ; 2) geographical disparity of poverty and vulnerability is substantial across the period and is increasing; 3) both poverty and vulnerability are associated with household characteristics, such as household head's educational attainment, in which region a household lives, and the infrastructure, such as the access to electricity power supply; 4) however, there are a few factors associated with not poverty, but vulnerability, such as, farm land size and the share of the farm land irrigated, that is, landholding or access to irrigation is a key to reducing vulnerability; and 5) the highly regressive taxation system not only created a large rural and urban gap but also increased the rural poverty and vulnerability levels. The last point implies that since the abolishment of the rural agriculture tax in 2006, we conjecture that the welfare of rural household would have been improved. This will have to be confirmed by future studies when more recent national household data are available. 


\section{References}

Azam. Md., and Katsushi. S. Imai, "Vulnerability and Poverty in Bangladesh," Chronic Poverty Research Centre working paper, no. 141, 2009.

Chaudhuri, Shubham, “Assessing vulnerability to poverty: concepts, empirical methods and illustrative examples," mimeo, New York, Columbia University, 2003.

Chaudhuri, Shubham, Jyotsna Jalan and Asep Suryahadi, “Assessing Household Vulnerability to Poverty: A Methodology and Estimates for Indonesia," Columbia University Department of Economics Discussion Paper No. 0102-52, New York, Columbia University, 2002.

Chen, Shaohua and Martin Ravallion, "China is poorer than we thought, but no less successful in the fight against poverty," Policy Research Working Paper Series 4621, The World Bank, 2008.

Foster, James, Joel Greer, and Erik Thorbecke, “A Class of Decomposable Poverty Indices," Econometrica, 52, 761-766, 1984.

Gaiha, Raghav and Katsushi Imai, "Measuring Vulnerability and Poverty in Rural India," in W. Naudé, A. Santos-Paulino and M. McGillivray (Eds.), Vulnerability in Developing Countries, 2009.

Griffin, Keith and Zhao Renwei (eds.), The Distribution of Income in China. New York, NY: St. Martin's Press, Inc., 1993.

Gustafsson, Björn, and Shi Li and Terry Sicular (eds.), Income Inequality and Public Policy in China Inequality and Public Policy in China, New York: Cambridge University Press, 2008. 
Imai, Katsushi, "Targeting versus Universalism: Is the Employment Guarantee Scheme in Maharashtra an Effective Way of Poverty Alleviation? Evidence for Rural India', Journal of Policy Modelling, 29 (1): 99-113, 2007.

Jalan, Jyotsna and Martin Ravallion, "Household income dynamics in Rural China". Policy Research Working Papers Series No. 2706, Washington D.C., The World Bank, 2001.

Jha, Raghbendra, Katsushi S. Imai and Raghav Gaiha, "Poverty, Undernutrition and Vulnerability in Rural India: Public Works versus Food Subsidy," Chronic Poverty Research Centre (CPRC) Working Paper No. 135, 2009.

Khan, Azizur Rahman, "Growth, Inequality, and Poverty: A Comparative Study of China's Experience in the Periods before and after the Asian Crisis," Chapter 6 of Gustafsson, Björn, and Shi Li and Terry Sicular (eds.), Income Inequality and Public Policy in China Inequality and Public Policy in China, New York: Cambridge University Press, 2008.

Knight, John and Song, Lina, The Rural-Urban Divide: Economic Disparities and Interactions in China. Oxford: Oxford University Press, 1999.

Ligon, Ethan, and Laura Schechter, “Measuring Vulnerability,” Economic Journal 113 (March), pp. C95-C102, 2003.

Lu, Mai and Calla Wiemer, "An End to China's Agriculture Tax." China: An International Journal 3(2): 320-330, 2005.

Lant Pritchett, Sudarno Sumarto, and Asep Suryahadi, "Quantifying Vulnerability to Poverty: A Proposed measure, Applied to Indonesia," Policy Research Working Paper No. 2437, Washington DC, The World Bank, 2000. 
Ravallion, Martin and Shaohua Chen, "China's (uneven) progress against poverty," Journal of Development Economics, 82(1):1-42, 2007.

Riskin, Carl. Zhao Renwei and Shi Li (eds.), China's Retreat from Equality: Income Distribution and Economic Transition. Armonk, NY: M. E.Sharpe, Inc., 2001.

Sicular, Terry, Yue Ximing, Björn Gustafsson, and Shi Li, "The Urban-Rural Income Gap and Inequality in China," Review of Income and Wealth, 53(1): 93-126, 2007.

Sato, Hiroshi, Shi Li and Yue Ximing, "The Redistributive Impact of Taxation in rural China, 1995-2002: An Evaluation of Rural Taxation Reform at the Turn of the Century," in Gustafsson, Li and Terry Sicular (eds.), Income Inequality and Public Policy in China Inequality and Public Policy in China, New York: Cambridge University Press, 2008.

Suryahadi, Asep, and Sudarno Sumarto, "Measuring Vulnerability to Poverty in Indonesia Before and After the Crisis," Paper presented at the $4^{\text {th }}$ Annual GDN International Conference, organised by IPALMO, Cairo (Jan 21), 2003.

Tao, Ran and Mingxing Liu, "Urban and Rural Household Taxation in China. Measurement, Comparison and Policy Implications", Journal of the Asia Pacific Economy, 10 (4): 485-505, 2005.

Wan, Guanghua, and Xiaobo Zhang, "Introduction: Rising inequality in China," Journal of Comparative Economics, 34: 651-3, 2006.

Wang, Xiaobing, and Jennifer Piesse, "The Welfare Effects of a Regressive Tax and Subsidy Policy: an Explanation of the Urban Rural Divide in China," forthcoming BWPI working paper, 2009. 
You, Jing, Bernard Walters, and Xiaobing Wang, "Vulnerability to Increasing Uncertainty in Post-reform Rural China," Economics, the University of Manchester, Working Paper, 2009.

Zhang, Yuan, and Guanghua, Wan, "An Empirical Analysis of Household Vulnerability in Rural China” Journal of the Asia Pacific Economy, 11(2): 196-212, 2006.

Zhang, Yuan, and Guanghua, Wan, "Can We Predict Vulnerability to Poverty?," UNU-WIDER Research Paper No. 2008/82, September 2008, Helsinki, 2008. 
Table 1 Average tax rate by household income decile

\begin{tabular}{cccc}
\hline Income decile & 1988 & 1995 & 2002 \\
\hline 1 (Bottom & & & \\
$10 \%)$ & 13.7 & 13.7 & 8.9 \\
2 & 7.3 & 7.3 & 5.6 \\
3 & 5.6 & 5.6 & 4.7 \\
4 & 4.7 & 5.9 & 4.1 \\
5 & 4.2 & 5.8 & 3.6 \\
6 & 4.2 & 4.9 & 3.4 \\
7 & 3.5 & 4.7 & 3.1 \\
8 & 3.2 & 4 & 2.7 \\
9 & 2.9 & 2.8 & 2.1 \\
10 & 1.8 & 1.3 & 1.4 \\
\hline
\end{tabular}

Table 2 Poverty Headcount Ratios in Rural China

\begin{tabular}{|c|c|c|c|c|c|c|c|c|c|}
\hline & \multicolumn{3}{|c|}{1988} & \multicolumn{3}{|c|}{1995} & \multicolumn{3}{|c|}{2002} \\
\hline & Case (A) & Case (B) & $(\boldsymbol{A})-(\boldsymbol{B})$ & Case (A) & Case (B) & (A)-(B) & Case (A) & Case (B) & (A)-(B) \\
\hline $\begin{array}{l}\text { Lower Poverty } \\
\text { line }\end{array}$ & $15.1 \%$ & $12.7 \%$ & $2.4 \%$ & $12.3 \%$ & $10.2 \%$ & $2.1 \%$ & $7.0 \%$ & $5.9 \%$ & $1.1 \%$ \\
\hline $\begin{array}{l}\text { Upper Poverty } \\
\text { line }\end{array}$ & $32.2 \%$ & $29.1 \%$ & $3.1 \%$ & $28.1 \%$ & $24.1 \%$ & $4.0 \%$ & $16.9 \%$ & $15.1 \%$ & $1.8 \%$ \\
\hline $\begin{array}{l}\text { Rural poverty } \\
\text { line }\end{array}$ & $\begin{array}{l}\text { Lower: } 3 \\
\text { Upper: } 52\end{array}$ & $\begin{array}{l}\text { in } 1988,8 \\
\text { n } 1988,1\end{array}$ & $\begin{array}{l}\text { in } 1995 \text { c } \\
7 \text { in } 1995\end{array}$ & $\begin{array}{l}876 \text { in } 2 \\
\text { d } 1252 \text { in }\end{array}$ & & & & & \\
\hline
\end{tabular}


Table 3 Estimation results of VEP (Vulnerability as Expected Poverty)

\begin{tabular}{|c|c|c|c|c|c|c|}
\hline & \multicolumn{2}{|c|}{1988} & \multicolumn{2}{|c|}{1995} & \multicolumn{2}{|c|}{2002} \\
\hline & $\begin{array}{l}\log (\text { per } \\
\text { capita } \\
\text { Income) }\end{array}$ & Variance & $\begin{array}{l}\log (\text { per } \\
\text { capita } \\
\text { Income) }\end{array}$ & Variance & $\begin{array}{l}\log (\text { per } \\
\text { capita } \\
\text { Income) }\end{array}$ & Variance \\
\hline \multirow[t]{2}{*}{ Headage } & 0.001 & -0.013 & -0.007 & -0.028 & -0.02 & 0.003 \\
\hline & $(0.46)$ & $(0.94)$ & $(1.56)$ & $(1.69)^{\star}$ & $(4.17)^{\star \star \star}$ & -0.14 \\
\hline \multirow[t]{2}{*}{ Headage2 } & -0.00001 & 0.0001 & 0.0001 & 0.0003 & 0.0002 & 0.00003 \\
\hline & $(0.39)$ & $(0.91)$ & $(1.04)$ & $(1.85)^{\star}$ & $(3.35)^{\star \star \star}$ & $(0.14)$ \\
\hline \multirow[t]{2}{*}{ Married } & -0.035 & -0.161 & 0.002 & 0.06 & 0.012 & -0.129 \\
\hline & $(1.65)^{\star}$ & $(1.97)^{\star \star}$ & $(0.05)$ & $(0.41)$ & $(0.38)$ & $(1.08)$ \\
\hline \multirow[t]{2}{*}{ Femaleshare } & -0.169 & -0.094 & -0.139 & -0.427 & -0.111 & 0.186 \\
\hline & $(4.96)^{\star \star \star}$ & $(0.65)$ & $(3.05)^{\star \star \star}$ & $(2.52)^{\star \star}$ & $(2.74)^{\star \star \star}$ & $(1.16)$ \\
\hline \multirow[t]{2}{*}{ Depburden } & -0.486 & 0.035 & -0.519 & -0.372 & -0.604 & -0.027 \\
\hline & $(16.87)^{\star \star \star}$ & $(0.29)$ & $(14.35)^{\star \star \star}$ & $(2.57)^{\star \star}$ & $(17.73)^{\star \star \star}$ & $(0.20)$ \\
\hline \multirow[t]{2}{*}{ Ratio_Party } & 0.7 & 0.285 & 0.682 & -0.077 & 0.578 & 0.156 \\
\hline & $(11.29)^{\star \star \star}$ & $(1.10)$ & $(9.78)^{\star \star \star}$ & $(0.32)$ & $(11.65)^{\star \star \star}$ & $(0.85)$ \\
\hline \multirow[t]{2}{*}{ Majority } & 0.056 & -0.235 & 0.052 & -0.147 & 0.029 & 0.035 \\
\hline & $(2.48)^{\star \star}$ & $(2.41)^{\star \star}$ & $(1.81)^{\star}$ & $(1.31)$ & $(1.32)$ & $(0.41)$ \\
\hline \multirow[t]{2}{*}{ Elementary_Head } & 0.111 & -0.002 & 0.014 & -0.02 & -0.01 & -0.183 \\
\hline & $(6.60)^{\star \star \star}$ & $(0.03)$ & $(0.45)$ & $(0.17)$ & $(0.23)$ & $(1.28)$ \\
\hline \multirow[t]{2}{*}{ Lowermiddle_Head } & 0.134 & -0.108 & 0.086 & 0.018 & 0.058 & -0.156 \\
\hline & $(7.09)^{\star \star \star}$ & $(1.25)$ & $(2.75)^{\star \star \star}$ & $(0.14)$ & $(1.40)$ & $(1.08)$ \\
\hline \multirow[t]{2}{*}{ Uppermiddle_Head } & 0.155 & -0.003 & 0.163 & -0.02 & 0.122 & -0.238 \\
\hline & $(6.34)^{\star \star \star}$ & $(0.03)$ & $(4.44)^{\star \star \star}$ & $(0.14)$ & $(2.83)^{\star \star \star}$ & $(1.53)$ \\
\hline \multirow[t]{2}{*}{ Technical_Head } & 0.183 & 0.168 & 0.086 & 0.384 & 0.233 & -0.088 \\
\hline & $(3.44)^{\star \star \star}$ & $(0.86)$ & $(1.25)$ & $(1.76)^{\star}$ & $(3.63)^{\star \star \star}$ & $(0.43)$ \\
\hline \multirow{2}{*}{ Higher_Head } & 0.146 & -0.089 & 0.336 & 0.014 & 0.306 & -0.146 \\
\hline & $(1.26)$ & $(0.18)$ & $(3.51)^{\star \star \star}$ & $(0.04)$ & $(3.96)^{\star \star \star}$ & $(0.54)$ \\
\hline \multirow[t]{2}{*}{ Land_farm } & -0.0002 & 0.001 & -0.0004 & -0.004 & -0.0001 & -0.007 \\
\hline & $(0.70)$ & $(2.48)^{\star \star}$ & $(0.27)$ & $(0.85)$ & $(0.05)$ & $(1.48)$ \\
\hline \multirow[t]{2}{*}{ Ratio_Irrigated } & 0.108 & -0.4 & -0.05 & 0.052 & 0.025 & -0.213 \\
\hline & $(1.93)^{\star}$ & (1.59) & $(0.60)$ & $(0.17)$ & $(0.30)$ & $(0.71)$ \\
\hline \multirow[t]{2}{*}{ Ratio_Irrigated2 } & 0.124 & 0.18 & 0.217 & -0.138 & 0.036 & 0.02 \\
\hline & $(2.21)^{\star \star}$ & $(0.71)$ & $(2.56)^{\star \star}$ & $(0.44)$ & $(0.44)$ & $(0.07)$ \\
\hline \multirow[t]{2}{*}{ NorthEast } & -0.18 & 0.8 & 0.282 & 0.138 & 0.036 & 0.156 \\
\hline & $(6.27)^{\star \star \star}$ & $(7.63)^{\star \star \star}$ & $(8.93)^{\star \star \star}$ & $(1.15)$ & $(0.88)$ & $(1.39)$ \\
\hline \multirow[t]{2}{*}{ NorthCoast } & -0.024 & 0.47 & 0.15 & 0.554 & 0.099 & 0.283 \\
\hline & $(1.25)$ & $(5.77)^{\star \star \star}$ & $(6.02)^{\star \star \star}$ & $(6.10)^{\star \star \star}$ & $(4.00)^{\star \star \star}$ & $(3.19)^{\star \star \star}$ \\
\hline \multirow[t]{2}{*}{ EastCoast } & 0.322 & 0.942 & 0.76 & 0.563 & 0.659 & 0.37 \\
\hline & $(14.10)^{\star \star \star}$ & $(10.66)^{\star \star \star}$ & $(27.69)^{\star \star \star}$ & $(5.31)^{\star \star \star}$ & $(24.07)^{\star \star \star}$ & $(3.90)^{\star \star \star}$ \\
\hline \multirow[t]{2}{*}{ SouthCoast } & 0.31 & 0.566 & 0.885 & 0.464 & 0.625 & 0.006 \\
\hline & $(12.70)^{\star \star \star}$ & $(5.70)^{\star \star \star}$ & $(25.44)^{\star \star \star}$ & $(3.73)^{\star \star \star}$ & $(21.50)^{\star \star \star}$ & $(0.05)$ \\
\hline \multirow[t]{2}{*}{ MYRiver } & -0.272 & 0.382 & -0.111 & 0.114 & -0.151 & 0.115 \\
\hline & $(14.94)^{\star \star \star}$ & $(4.66)^{\star \star \star}$ & $(4.98)^{\star \star \star}$ & $(1.23)$ & $(6.81)^{\star \star \star}$ & $(1.34)$ \\
\hline SouthWest & -0.03 & 0.255 & -0.05 & -0.145 & -0.097 & -0.3 \\
\hline & $(1.70)^{\star}$ & $(3.04)^{\star \star \star}$ & $(2.25)^{\star \star}$ & $(1.65)^{\star}$ & $(5.02)^{\star \star \star}$ & $(3.58)^{\star \star \star}$ \\
\hline NorthWest & -0.219 & 0.255 & -0.321 & 0.183 & -0.058 & 0.229 \\
\hline & $(8.70)^{\star \star \star}$ & $(2.16)^{\star \star}$ & $(8.39)^{\star \star \star}$ & (1.17) & $(1.76)^{\star}$ & $(2.15)^{\star \star}$ \\
\hline
\end{tabular}




\begin{tabular}{|c|c|c|c|c|c|c|}
\hline Hilly & $\begin{array}{l}-0.02 \\
(1.48)\end{array}$ & $\begin{array}{c}-0.15 \\
(2.54)^{\star \star}\end{array}$ & $\begin{array}{c}-0.151 \\
(8.63)^{\star \star \star}\end{array}$ & $\begin{array}{c}0.233 \\
(3.49)^{\star \star \star}\end{array}$ & $\begin{array}{c}-0.056 \\
(3.47)^{\star \star \star}\end{array}$ & $\begin{array}{l}-0.084 \\
(1.33)\end{array}$ \\
\hline Mountainous & $\begin{array}{c}-0.077 \\
(4.74)^{\star \star \star}\end{array}$ & $\begin{array}{c}-0.143 \\
(2.02)^{\star \star}\end{array}$ & $\begin{array}{c}-0.308 \\
(14.49)^{\star \star \star}\end{array}$ & $\begin{array}{l}0.124 \\
(1.54)\end{array}$ & $\begin{array}{c}-0.33 \\
(17.63)^{\star \star \star}\end{array}$ & $\begin{array}{c}0.231 \\
(3.37)^{\star \star \star}\end{array}$ \\
\hline Electricity & $\begin{array}{c}0.179 \\
(11.26)^{\star \star \star}\end{array}$ & $\begin{array}{c}0.15 \\
(2.08)^{\star \star}\end{array}$ & $\begin{array}{c}0.173 \\
(3.82)^{\star \star \star}\end{array}$ & $\begin{array}{c}0.516 \\
(2.30)^{\star \star}\end{array}$ & $\begin{array}{c}0.334 \\
(3.69)^{\star \star \star}\end{array}$ & $\begin{array}{l}0.467 \\
(0.95)\end{array}$ \\
\hline Constant & $\begin{array}{c}6.34 \\
(81.41) \\
\end{array}$ & $\begin{array}{c}-2.396 \\
(7.13) \\
\end{array}$ & $\begin{array}{c}7.47 \\
(63.16) \\
\end{array}$ & $\begin{array}{c}-2.309 \\
(4.86) \\
\end{array}$ & $\begin{array}{r}8.038 \\
(52.20) \\
\end{array}$ & $\begin{array}{c}-2.976 \\
(4.32) \\
\end{array}$ \\
\hline Observations & 9365 & 9365 & 7785 & 7785 & 9139 & 9139 \\
\hline R-squared & 0.24 & 0.02 & 0.32 & 0.02 & 0.26 & 0.01 \\
\hline $\begin{array}{c}\text { Joint } \\
\text { Significance }\end{array}$ & $\begin{array}{c}\mathrm{F}(25,9339) \\
=122.43\end{array}$ & $\begin{array}{c}\mathrm{F}(25,9339) \\
\quad=9.41\end{array}$ & $\begin{array}{c}\mathrm{F}(25,7759) \\
=159.50\end{array}$ & $\begin{array}{l}\mathrm{F}(25,7759) \\
\quad=4.95\end{array}$ & $\begin{array}{c}\mathrm{F}(25,9113) \\
=132.65\end{array}$ & $\begin{array}{c}\mathrm{F}(25,9113) \\
\quad=5.16\end{array}$ \\
\hline Prob $>F$ & 0.0000 & 0.0000 & 0.0000 & 0.0000 & 0.0000 & 0.0000 \\
\hline
\end{tabular}

Robust $\mathrm{t}$ statistics in

parentheses

* significant at $10 \%$; ** significant at $5 \%$; ** significant at $1 \%$ 


\section{Table 4. Poverty head count ratio and the VEP for rural China}

\begin{tabular}{|c|c|c|c|c|c|c|c|c|c|c|}
\hline & & & 1988 & & & 1995 & & & 2002 & \\
\hline & & Case (A) & Case (B) & (A)-(B) & Case (A) & Case (B) & (A)-(B) & Case (A) & Case (B) & (A)-(B) \\
\hline & & After tax & Before tax & difference & After tax & Before tax & difference & After tax & Before tax & Difference \\
\hline \multirow{3}{*}{$\begin{array}{l}\text { The } \\
\text { estimated } \\
\text { rural VEP } \\
\text { (with upper } \\
\text { line) }\end{array}$} & $\begin{array}{c}\hat{V}_{i} \geq 0.5 \\
\text { High vulnerable }\end{array}$ & $\begin{array}{c}2,204 \\
\text { households } \\
(23.5 \%)\end{array}$ & $\begin{array}{c}1,626 \\
(17.4 \%)\end{array}$ & $6.1 \%$ & $\begin{array}{c}1,279 \\
(16.4 \%)\end{array}$ & $\begin{array}{c}1,016 \\
(13.1 \%)\end{array}$ & $3.3 \%$ & $\begin{array}{c}240 \\
(2.6 \%)\end{array}$ & $\begin{array}{c}182 \\
(2.0 \%)\end{array}$ & $0.6 \%$ \\
\hline & $\begin{array}{l}0.25 \leq \hat{V}_{i}<0.5 \\
\text { Low vulnerable }\end{array}$ & $\begin{array}{c}807 \\
(8.6 \%)\end{array}$ & $\begin{array}{c}721 \\
(7.7 \%)\end{array}$ & $0.9 \%$ & $\begin{array}{c}489 \\
(6.3 \%)\end{array}$ & $\begin{array}{c}374 \\
(4.8 \%)\end{array}$ & $1.5 \%$ & $\begin{array}{c}260 \\
(2.9 \%)\end{array}$ & $\begin{array}{c}207 \\
(2.3 \%)\end{array}$ & $0.6 \%$ \\
\hline & $\begin{array}{r}\hat{V}_{i}<0.25 \\
\text { Non vulnerable }\end{array}$ & $\begin{array}{c}6,354 \\
(67.9 \%)\end{array}$ & $\begin{array}{c}7,018 \\
(74.9 \%)\end{array}$ & $-7.0 \%$ & $\begin{array}{c}6,017 \\
(77.3 \%)\end{array}$ & $\begin{array}{c}6,395 \\
(82.1 \%)\end{array}$ & $-4.8 \%$ & $\begin{array}{c}8,639 \\
(94.5 \%)\end{array}$ & $\begin{array}{c}8,750 \\
(95.7 \%)\end{array}$ & $-1.2 \%$ \\
\hline
\end{tabular}

Rural upper poverty line: 525 in 1988, 1157 in 1995 and 1252 in 2002

Poverty lines for 1988 were estimated by deflating poverty lines of 2002 in Khan(2008) using rural CPI 
Table 5 Determinants of Poverty and Vulnerability

\begin{tabular}{|c|c|c|c|c|c|c|}
\hline & \multicolumn{3}{|c|}{$\begin{array}{c}\text { Determinants of Poverty } \\
\text { (Probit Model) } \\
\text { (Based on Upper Poverty Lines) }\end{array}$} & \multicolumn{3}{|c|}{$\begin{array}{c}\text { Determinants of Vulnerability or VEP } \\
\text { (OLS) } \\
\text { (Based on Upper Poverty Lines) } \\
\text { (Based on Income after Tax) }\end{array}$} \\
\hline & 1988 & 1995 & 2002 & 1988 & 1995 & 2002 \\
\hline & $\begin{array}{c}\text { Coef. } \\
\text { (z value) }\end{array}$ & $\begin{array}{c}\text { Coef. } \\
\text { (z value) }\end{array}$ & $\begin{array}{c}\text { Coef. } \\
\text { (z value) }\end{array}$ & $\begin{array}{c}\text { Coef. } \\
\text { (t value) }\end{array}$ & $\begin{array}{c}\text { Coef. } \\
\text { (t value) }\end{array}$ & $\begin{array}{c}\text { Coef. } \\
\text { (t value) }\end{array}$ \\
\hline Headage & $\begin{array}{l}0.003 \\
(1.14)\end{array}$ & $\begin{array}{c}0.001 \\
(0.33) \\
-\end{array}$ & $\begin{array}{c}0.007 \\
(2.42)^{\star \star}\end{array}$ & $\begin{array}{c}-0.001 \\
(1.25)\end{array}$ & $\begin{array}{c}0.008 \\
(6.46)^{\star \star \star}\end{array}$ & $\begin{array}{c}0.004 \\
(4.39)^{\star \star \star}\end{array}$ \\
\hline Headage 2 & $\begin{array}{c}-0.00004 \\
(1.19)\end{array}$ & $\begin{array}{c}0.0000008 \\
(0.24)\end{array}$ & $\begin{array}{l}-0.0001 \\
(1.97)^{\star \star}\end{array}$ & $\begin{array}{c}0.00001 \\
(1.31)\end{array}$ & $\begin{array}{c}-0.0001 \\
(5.44)^{\star \star \star \star}\end{array}$ & $\begin{array}{l}-0.00003 \\
(3.06)^{\star \star \star}\end{array}$ \\
\hline Married & $\begin{array}{l}0.025 \\
(1.44)\end{array}$ & $\begin{array}{c}-0.003 \\
(0.10)\end{array}$ & $\begin{array}{c}-0.016 \\
(0.89)\end{array}$ & $\begin{array}{c}0.02 \\
(3.71)^{\star \star \star}\end{array}$ & $\begin{array}{l}-0.016 \\
(1.81)^{\star}\end{array}$ & $\begin{array}{c}-0.014 \\
(2.08)^{\star \star}\end{array}$ \\
\hline Femaleshare & $\begin{array}{c}0.086 \\
(2.83)^{\star \star \star}\end{array}$ & $\begin{array}{l}0.043 \\
(1.30)\end{array}$ & $\begin{array}{c}0.068 \\
(2.93)^{\star \star \star}\end{array}$ & $\begin{array}{c}0.154 \\
(15.45)^{\star \star \star}\end{array}$ & $\begin{array}{c}0.081 \\
(7.32)^{\star \star \star}\end{array}$ & $\begin{array}{c}0.02 \\
(2.74)^{\star \star \star}\end{array}$ \\
\hline Depburden & $\begin{array}{c}0.319 \\
(12.09)^{\star \star \star}\end{array}$ & $\begin{array}{c}0.253 \\
(9.15)^{\star \star \star}\end{array}$ & $\begin{array}{c}0.204 \\
(10.49)^{\star \star \star}\end{array}$ & $\begin{array}{c}0.48 \\
(51.45)^{\star \star \star}\end{array}$ & $\begin{array}{c}0.391 \\
(36.71)^{\star \star \star}\end{array}$ & $\begin{array}{c}0.198 \\
(21.86)^{\star \star \star}\end{array}$ \\
\hline Ratio_Party & $\begin{array}{c}-0.442 \\
(7.02)^{\star \star \star}\end{array}$ & $\begin{array}{c}-0.423 \\
(7.20)^{\star \star \star}\end{array}$ & $\begin{array}{c}-0.183 \\
(5.67)^{\star \star \star}\end{array}$ & $\begin{array}{c}-0.379 \\
(14.41)^{\star \star \star}\end{array}$ & $\begin{array}{c}-0.176 \\
(8.86)^{\star \star \star}\end{array}$ & $\begin{array}{c}-0.054 \\
(9.18)^{\star \star \star}\end{array}$ \\
\hline Majority & $\begin{array}{c}-0.072 \\
(3.47)^{\star \star \star}\end{array}$ & $\begin{array}{c}-0.047 \\
(2.21)^{\star \star}\end{array}$ & $\begin{array}{c}-0.003 \\
(0.31)\end{array}$ & $\begin{array}{c}-0.098 \\
(13.73)^{\star \star \star}\end{array}$ & $\begin{array}{c}-0.096 \\
(10.44)^{\star \star \star}\end{array}$ & $\begin{array}{c}-0.019 \\
(3.68)^{\star \star \star}\end{array}$ \\
\hline Elementary_Head & $\begin{array}{c}-0.082 \\
(5.31)^{\star \star \star}\end{array}$ & $\begin{array}{l}-0.01 \\
(0.44)\end{array}$ & $\begin{array}{c}0.03 \\
(1.33)\end{array}$ & $\begin{array}{c}-0.12 \\
(22.21)^{\star \star \star}\end{array}$ & $\begin{array}{c}-0.034 \\
(4.50)^{\star \star \star}\end{array}$ & $\begin{array}{c}-0.047 \\
(4.48)^{\star \star \star}\end{array}$ \\
\hline Lowermiddle_Head & $\begin{array}{c}-0.101 \\
(5.99)^{\star \star \star}\end{array}$ & $\begin{array}{c}-0.056 \\
(2.34)^{\star \star}\end{array}$ & $\begin{array}{c}0 \\
(0.02)\end{array}$ & $\begin{array}{c}-0.151 \\
(24.85)^{\star \star \star}\end{array}$ & $\begin{array}{c}-0.098 \\
(12.59)^{\star \star \star}\end{array}$ & $\begin{array}{c}-0.074 \\
(7.22)^{\star \star \star}\end{array}$ \\
\hline Uppermiddle_Head & $\begin{array}{c}-0.092 \\
(4.42)^{\star \star \star}\end{array}$ & $\begin{array}{c}-0.094 \\
(3.68)^{\star \star \star \star}\end{array}$ & $\begin{array}{c}-0.024 \\
(1.06)\end{array}$ & $\begin{array}{c}-0.164 \\
(21.97)^{\star \star \star}\end{array}$ & $\begin{array}{c}-0.141 \\
(16.00)^{\star \star \star}\end{array}$ & $\begin{array}{c}-0.082 \\
(7.90)^{\star \star \star}\end{array}$ \\
\hline Technical_Head & $\begin{array}{c}-0.14 \\
(3.29)^{\star \star \star}\end{array}$ & $\begin{array}{l}-0.04 \\
(0.86)\end{array}$ & $\begin{array}{c}-0.071 \\
(2.45)^{\star \star}\end{array}$ & $\begin{array}{c}-0.183 \\
(14.13)^{\star \star \star}\end{array}$ & $\begin{array}{c}-0.063 \\
(4.86)^{\star \star \star}\end{array}$ & $\begin{array}{c}-0.086 \\
(7.68)^{\star \star \star}\end{array}$ \\
\hline Higher_Head & $\begin{array}{c}-0.13 \\
(1.90)^{\star}\end{array}$ & $\begin{array}{c}-0.146 \\
(2.18)^{\star \star}\end{array}$ & $\begin{array}{c}-0.119 \\
(3.41)^{\star \star \star}\end{array}$ & $\begin{array}{l}0.003 \\
(0.16)\end{array}$ & $\begin{array}{c}-0.118 \\
(4.49)^{\star \star \star}\end{array}$ & $\begin{array}{c}-0.073 \\
(6.08)^{\star \star \star}\end{array}$ \\
\hline Land_farm & $\begin{array}{c}0.0001 \\
(0.69)\end{array}$ & $\begin{array}{c}-0.001 \\
(0.62)\end{array}$ & $\begin{array}{c}-0.001 \\
(0.95)\end{array}$ & $\begin{array}{c}0.0002 \\
(8.45)^{\star \star \star}\end{array}$ & $\begin{array}{c}0.001 \\
(3.90)^{\star \star \star}\end{array}$ & $\begin{array}{c}0.001 \\
(4.91)^{\star \star \star}\end{array}$ \\
\hline Ratio_Irrigated & $\begin{array}{c}-0.119 \\
(2.26)^{\star \star}\end{array}$ & $\begin{array}{c}0.05 \\
(0.84)\end{array}$ & $\begin{array}{c}-0.025 \\
(0.55)\end{array}$ & $\begin{array}{c}-0.363 \\
(21.10)^{\star \star *}\end{array}$ & $\begin{array}{c}-0.209 \\
(10.28)^{\star \star \star}\end{array}$ & $\begin{array}{c}-0.063 \\
(4.50)^{\star \star \star}\end{array}$ \\
\hline Ratio_Irrigated2 & $\begin{array}{l}-0.055 \\
(1.02)\end{array}$ & $\begin{array}{c}-0.165 \\
(2.70)^{\star \star \star}\end{array}$ & $\begin{array}{c}-0.006 \\
(0.14)\end{array}$ & $\begin{array}{c}0.142 \\
(8.38)^{\star \star \star}\end{array}$ & $\begin{array}{c}0.075 \\
(3.81)^{\star \star \star}\end{array}$ & $\begin{array}{c}0.038 \\
(2.85)^{\star \star \star}\end{array}$ \\
\hline NorthEast & $\begin{array}{c}0.199 \\
(8.65)^{\star \star \star}\end{array}$ & $\begin{array}{c}-0.109 \\
(5.13)^{\star \star \star}\end{array}$ & $\begin{array}{l}0.009 \\
(0.48)\end{array}$ & $\begin{array}{c}0.287 \\
(37.24)^{\star \star \star}\end{array}$ & $\begin{array}{c}-0.153 \\
(21.22)^{\star \star \star}\end{array}$ & $\begin{array}{c}-0.014 \\
(4.28)^{\star \star \star}\end{array}$ \\
\hline NorthCoast & $\begin{array}{c}0.082 \\
(4.38)^{\star \star \star}\end{array}$ & $\begin{array}{c}-0.003 \\
(0.20)\end{array}$ & $\begin{array}{l}0.015 \\
(1.06)\end{array}$ & $\begin{array}{c}0.051 \\
(10.69)^{\star \star \star}\end{array}$ & $\begin{array}{c}-0.01 \\
(1.92)^{\star}\end{array}$ & $\begin{array}{c}0.014 \\
(6.16)^{\star \star \star}\end{array}$ \\
\hline EastCoast & $\begin{array}{c}-0.054 \\
(2.55)^{\star \star}\end{array}$ & $\begin{array}{c}-0.213 \\
(10.53)^{\star \star \star}\end{array}$ & $\begin{array}{c}-0.109 \\
(8.19)^{\star \star \star}\end{array}$ & $\begin{array}{l}0.008 \\
(1.20)\end{array}$ & $\begin{array}{c}-0.034 \\
(4.98)^{\star \star \star}\end{array}$ & $\begin{array}{c}-0.009 \\
(3.30)^{\star \star \star}\end{array}$ \\
\hline SouthCoast & $\begin{array}{c}-0.13 \\
(5.83)^{\star \star \star}\end{array}$ & $\begin{array}{c}-0.215 \\
(9.96)^{\star \star \star}\end{array}$ & $\begin{array}{c}-0.136 \\
(8.25)^{\star \star \star}\end{array}$ & $\begin{array}{c}-0.062 \\
(8.93)^{\star \star \star}\end{array}$ & $\begin{array}{c}-0.185 \\
(18.44)^{\star \star \star}\end{array}$ & $\begin{array}{c}-0.04 \\
(10.50)^{\star \star \star}\end{array}$ \\
\hline MYRiver & $\begin{array}{c}0.28 \\
(15.38)^{\star \star \star}\end{array}$ & $\begin{array}{c}0.09 \\
(5.11)^{\star \star \star}\end{array}$ & $\begin{array}{c}0.078 \\
(5.55)^{\star \star \star}\end{array}$ & $\begin{array}{c}0.453 \\
(71.28)^{\star \star \star}\end{array}$ & $\begin{array}{c}0.105 \\
(17.16)^{\star \star \star}\end{array}$ & $\begin{array}{c}0.03 \\
(8.49)^{\star \star \star}\end{array}$ \\
\hline SouthWest & $\begin{array}{c}0.084 \\
(4.67)^{\star \star \star}\end{array}$ & $\begin{array}{c}0.079 \\
(4.74)^{\star \star \star}\end{array}$ & $\begin{array}{c}0.035 \\
(2.85)^{\star \star \star}\end{array}$ & $\begin{array}{c}0.046 \\
(9.08)^{\star \star \star}\end{array}$ & $\begin{array}{c}0.104 \\
(16.15)^{\star \star \star}\end{array}$ & $\begin{array}{c}0.048 \\
(12.71)^{\star \star \star}\end{array}$ \\
\hline NorthWest & $\begin{array}{c}0.266 \\
(9.85)^{\star \star \star}\end{array}$ & $\begin{array}{c}0.311 \\
(9.30)^{\star \star \star}\end{array}$ & $\begin{array}{c}0.078 \\
(4.40)^{\star \star \star}\end{array}$ & $\begin{array}{c}0.347 \\
(40.74)^{\star \star \star}\end{array}$ & $\begin{array}{c}0.425 \\
(45.38)^{\star \star \star}\end{array}$ & $\begin{array}{c}-0.018 \\
(3.56)^{\star \star \star}\end{array}$ \\
\hline Hilly & $\begin{array}{c}-0.011 \\
(0.90)\end{array}$ & $\begin{array}{c}0.108 \\
(8.04)^{\star \star \star}\end{array}$ & $\begin{array}{l}0.011 \\
(1.07)\end{array}$ & $\begin{array}{c}0.031 \\
(7.68)^{\star \star \star}\end{array}$ & $\begin{array}{c}0.075 \\
(19.11)^{\star \star \star}\end{array}$ & $\begin{array}{c}-0.004 \\
(1.97)^{\star \star}\end{array}$ \\
\hline Mountainous & $\begin{array}{c}0.045 \\
(2.97)^{\star \star \star}\end{array}$ & $\begin{array}{c}0.189 \\
(11.30)^{\star \star \star}\end{array}$ & $\begin{array}{c}0.189 \\
(15.69)^{\star \star \star}\end{array}$ & $\begin{array}{c}0.139 \\
(27.40)^{\star \star \star}\end{array}$ & $\begin{array}{c}0.355 \\
(50.22)^{\star \star \star}\end{array}$ & $\begin{array}{c}0.121 \\
(29.91)^{\star \star \star}\end{array}$ \\
\hline Electricity & $\begin{array}{c}-0.15 \\
(9.55)^{\star \star \star}\end{array}$ & $\begin{array}{c}-0.168 \\
(3.95)^{\star \star \star}\end{array}$ & $\begin{array}{c}-0.182 \\
(2.08)^{\star \star}\end{array}$ & $\begin{array}{c}-0.262 \\
(42.98)^{\star \star \star} \\
0.416 \\
(18.23)\end{array}$ & $\begin{array}{l}-0.242 \\
(21.51)^{\star \star \star} \\
0.194 \\
(6.06)\end{array}$ & $\begin{array}{c}-\mathbf{0 . 4 5 1} \\
(25.84)^{\star \star \star} \\
0.386 \\
(12.80)\end{array}$ \\
\hline Observations & 9365 & 7785 & 9139 & 9365 & 7785 & 9139 \\
\hline Pseudo R2 & 0.15 & 0.17 & 0.14 & 0.79 & 0.76 & 0.44 \\
\hline Wald chi2 (26) & 1477.27 & 1225.52 & 887.19 & $\begin{array}{l}F(25,9339) \\
=1406.44\end{array}$ & $\begin{array}{l}F(25,7759) \\
=1153.15\end{array}$ & $\begin{array}{l}F(25,9113) \\
\quad=126.39\end{array}$ \\
\hline Prob > chi 2 & 0.0000 & 0.0000 & 0.0000 & 0.0000 & 0.0000 & 0.0000 \\
\hline
\end{tabular}

Robust $\mathrm{z}$ statistics or $\mathrm{t}$ statistics in parentheses

$*$ significant at $10 \%$; * significant at $5 \%$; *** significant at $1 \%$ 
Table 6 The regional distribution of poverty and vulnerability based on upper poverty line (\%)

\begin{tabular}{lcccccccc} 
& \multicolumn{3}{c}{ Poverty Head Count Ratio } & & \multicolumn{3}{c}{ Vulnerability (VEP) } \\
\cline { 2 - 5 } \cline { 6 - 8 } & 1988 & 1995 & 2002 & & 1988 & 1995 & 2002 \\
\hline Beijing & 8.6 & 1.0 & 1.7 & & 7.96 & 2.02 & 1.01 \\
Hebei & 28.1 & 21.7 & 18.4 & & 6.84 & 1.10 & 0.08 \\
Shanxi & 48.2 & 48.3 & 18.5 & & 59.28 & 34.77 & 7.16 \\
Liaoning & 25.0 & 21.7 & 17.1 & & 41.55 & 3.43 & 1.70 \\
Jilin & 36.5 & 17.4 & 11.9 & & 40.23 & 0.54 & 0.22 \\
Jiangsu & 24.1 & 3.4 & 1.6 & & 0.50 & 0.001 & 0.001 \\
Zhejiang & 4.4 & 4.8 & 6.6 & & 0.18 & 0.03 & 0.03 \\
Anhui & 33.2 & 27.6 & 18.0 & & 14.98 & 9.39 & 0.42 \\
Jiangxi & 23.5 & 27.1 & 11.6 & & 4.80 & 13.16 & 1.20 \\
Shandong & 26.4 & 18.9 & 9.3 & & 6.62 & 1.14 & 0.08 \\
Henan & 49.8 & 19.9 & 13.6 & & 63.19 & 15.63 & 2.30 \\
Hubei & 18.4 & 23.9 & 11.8 & & 2.10 & 12.77 & 1.14 \\
Hunan & 11.4 & 37.9 & 18.2 & & 4.71 & 25.88 & 3.17 \\
Guangdong & 4.8 & 6.1 & 2.1 & & 0.28 & 0.003 & 0.003 \\
Guangxi & 37.8 & - & 23.3 & & 18.79 & - & 7.53 \\
Sichuan & 30.6 & 43.0 & 11.0 & & 17.82 & 24.07 & 2.63 \\
Guizhou & 56.1 & 59.2 & 48.2 & & 53.14 & 76.42 & 26.33 \\
Yunnan & 44.3 & 45.0 & 38.8 & & 45.40 & 43.71 & 17.14 \\
Shaanxi & 58.0 & 56.9 & 39.8 & & 65.41 & 26.18 & 7.01 \\
Gansu & 67.5 & 68.0 & 40.4 & & 67.29 & 78.56 & 11.09 \\
\hline
\end{tabular}


Appendix: Description and Summary

\section{Statistics of Variables}

\begin{tabular}{|c|c|c|c|c|c|c|c|c|c|c|c|c|c|c|c|c|}
\hline \multirow[b]{3}{*}{ Variable } & \multirow{3}{*}{ Description } & \multirow{2}{*}{\multicolumn{5}{|c|}{$\frac{1988}{S t d}$}} & \multirow{2}{*}{\multicolumn{5}{|c|}{$\frac{1995}{\text { Std. }}$}} & \multicolumn{4}{|c|}{2002} & \multirow[b]{3}{*}{ Max } \\
\hline & & & & & & & & & & & & & & Std. & & \\
\hline & & Obs & Mean & Dev. & Min & Max & Obs & Mean & Dev. & Min & $\operatorname{Max}$ & Obs & Mean & Dev. & Min & \\
\hline $\begin{array}{l}\text { Log } \\
\text { (consumption) }\end{array}$ & $\begin{array}{l}\text { Log of per capita } \\
\text { household income }\end{array}$ & 10162 & 6.501 & 0.629 & 0.405 & 9.962 & 7941 & 7.469 & 0.755 & 1.678 & 10.906 & 9175 & 7.751 & 0.699 & 0.405 & 10.864 \\
\hline Headage & Age of a household's head & 10153 & 43.248 & 11.385 & 0 & 86 & 7941 & 44.056 & 10.551 & 0 & 95 & 9175 & 46.395 & 10.307 & 16 & 88 \\
\hline Married & Whether the household head has a spouse & 10162 & 0.919 & 0.307 & 0 & 6 & 7941 & 0.965 & 0.185 & 0 & 1 & 9168 & 0.960 & 0.196 & 0 & 1 \\
\hline Femaleshare & $\begin{array}{l}\text { Share of number of female in total household members } \\
\text { Share of household members under } 15 \text { years old or }\end{array}$ & 10162 & 0.484 & 0.165 & 0 & 1 & 7941 & 0.482 & 0.157 & 0 & 1 & 9175 & 0.474 & 0.152 & 0 & 1 \\
\hline Depburden & $\begin{array}{l}\text { above } 65 \text { years old in total household members } \\
\text { Share of numbers of the members of the communist party }\end{array}$ & 10162 & 0.327 & 0.213 & 0 & 1 & 7941 & 0.286 & 0.218 & 0 & 1 & 9175 & 0.237 & 0.212 & 0 & 1 \\
\hline Ratio_Party & $\begin{array}{l}\text { in total household members } \\
\text { Whether the household belongs to ethnic majority or not }\end{array}$ & 10162 & 0.036 & 0.092 & 0 & 1 & 7941 & 0.043 & 0.108 & 0 & 1 & 9175 & 0.064 & 0.138 & 0 & 1 \\
\hline Majority & (majority=1 / minority=0) & 9855 & 0.928 & 0.258 & 0 & 1 & 7796 & 0.931 & 0.254 & 0 & 1 & 9166 & 0.876 & 0.329 & 0 & 1 \\
\hline Elementary d & $\begin{array}{l}\text { Whether the education attainment of the household head } \\
\text { was from elementary school or not } \\
\text { Whether the education attainment of the household head }\end{array}$ & 10162 & 0.412 & 0.492 & 0 & 1 & 7921 & 0.377 & 0.485 & 0 & 1 & 9175 & 0.308 & 0.462 & 0 & 1 \\
\hline Lowermiddl $\sim \mathrm{d}$ & $\begin{array}{l}\text { was from lower middle school or not } \\
\text { Whether the education attainment of the household head }\end{array}$ & 10162 & 0.306 & 0.461 & 0 & 1 & 7921 & 0.418 & 0.493 & 0 & 1 & 9175 & 0.479 & 0.500 & 0 & 1 \\
\hline Uppermiddl $\sim \mathrm{d}$ & $\begin{array}{l}\text { was from upper middle school or not } \\
\text { Whether the education attainment of the household head }\end{array}$ & 10162 & 0.101 & 0.301 & 0 & 1 & 7921 & 0.123 & 0.329 & 0 & 1 & 9175 & 0.152 & 0.359 & 0 & 1 \\
\hline Technical_ d & $\begin{array}{l}\text { was from technical school or not } \\
\text { Whether the education attainment of the household head }\end{array}$ & 10162 & 0.012 & 0.108 & 0 & 1 & 7921 & 0.016 & 0.124 & 0 & 1 & 9175 & 0.026 & 0.160 & 0 & 1 \\
\hline Higher_Head & was from college or university & 10162 & 0.005 & 0.071 & 0 & 1 & 7921 & 0.005 & 0.073 & 0 & 1 & 9175 & 0.009 & 0.094 & 0 & 1 \\
\hline Land_farm & The size of the household's farm land & 9750 & 11.915 & 37.131 & 0.1 & 970 & 7941 & 6.346 & 5.808 & 0 & 54.1 & 9175 & 6.083 & 7.149 & 0 & 180 \\
\hline Ratio_Irri d & The ratio of irrigated land to the total farm land & 10162 & 0.454 & 0.427 & 0 & 1 & 7941 & 0.516 & 0.432 & 0 & 1 & 9175 & 0.519 & 0.426 & 0 & 1 \\
\hline NorthEast & Whether the household is located in north east region & 10162 & 0.087 & 0.282 & 0 & 1 & 7941 & 0.075 & 0.264 & 0 & 1 & 9175 & 0.101 & 0.301 & 0 & 1 \\
\hline NorthCoast & Whether the household is located in north coast region & 10162 & 0.148 & 0.355 & 0 & 1 & 7941 & 0.163 & 0.369 & 0 & 1 & 9175 & 0.126 & 0.332 & 0 & 1 \\
\hline EastCoast & Whether the household is located in east coast region & 10162 & 0.103 & 0.305 & 0 & 1 & 7941 & 0.113 & 0.316 & 0 & 1 & 9175 & 0.104 & 0.306 & 0 & 1 \\
\hline SouthCoast & $\begin{array}{l}\text { Whether the household is located in south coast region } \\
\text { Whether the household is located in }\end{array}$ & 10162 & 0.081 & 0.273 & 0 & 1 & 7941 & 0.062 & 0.242 & 0 & 1 & 9175 & 0.058 & 0.233 & 0 & 1 \\
\hline MYRiver & middle yellow river region & 10162 & 0.163 & 0.370 & 0 & 1 & 7941 & 0.163 & 0.369 & 0 & 1 & 9175 & 0.142 & 0.349 & 0 & 1 \\
\hline SouthWest & Whether the household is located in south west region & 10162 & 0.178 & 0.383 & 0 & 1 & 7941 & 0.174 & 0.379 & 0 & 1 & 9175 & 0.192 & 0.394 & 0 & 1 \\
\hline NorthWest & Whether the household is located in north west region & 10162 & 0.051 & 0.220 & 0 & 1 & 7941 & 0.038 & 0.191 & 0 & 1 & 9175 & 0.077 & 0.267 & 0 & 1 \\
\hline
\end{tabular}




\begin{tabular}{|c|c|c|c|c|c|c|c|c|c|c|c|c|c|c|c|c|}
\hline Hilly & Whether the household is located in hilly area & 10162 & 0.304 & 0.460 & 0 & 1 & 7941 & 0.302 & 0.459 & 0 & 1 & 9155 & 0.308 & 0.462 & 0 & 1 \\
\hline Mountainous & $\begin{array}{l}\text { Whether the household is located in mountain area } \\
\text { Whether the household belongs to the village }\end{array}$ & 10162 & 0.200 & 0.400 & 0 & 1 & 7941 & 0.230 & 0.421 & 0 & 1 & 9155 & 0.218 & 0.413 & 0 & 1 \\
\hline Electricity & with power supply or not. & 10059 & 0.869 & 0.338 & 0 & 1 & 7941 & 0.984 & 0.126 & 0 & 1 & 9175 & 0.998 & 0.047 & 0 & 1 \\
\hline
\end{tabular}

1. The base group for the household head educational attainment is illiterate.

2. Provinces in China is divided into 8 regions as follows: Northeast region: Liaoning, Jilin, Heilongijang; North coast region: Beijing, Tianjin, Hebei, Shandong; East coast region: Shanghai, Jiangsu, Zhejiang; South coast region: Fujian, Guangdong, Hainan; Middle Yellow River region, Shaanxi, Shanxi, Henan, Neimenggu; Middle changjiang region: Hubei, Hunan, Jiangxi, Anhui; Southwest region, Yunnan, Guizhou, Sichuan, Chongqing, Guangxi; Northwest region, Gansu, Qinghai, Ningxia, Xizang, Xinjiang. 3. The base group for the regional variables is middle Changjiang (whether the household is located in middle Changiiang region).

4. There is only one common variable (Access to electricity) for village information throughout CHIP 1988, 1995 and 2002 although 1995 and 2002 have a few variables for the village. 